\title{
Village as a Basic of Safe Migration: The Enforcement of Head of Village and Local Regulation (Perdes) as a Strategy to Prevent Human Trafficking in Banyumas Central Java
}

\author{
Tyas R Wulan, Sri Wijayanti, Dalhar Shodiq, Wita Ramadhanti \\ Universitas Jenderal Soedirman \\ Purwokerto, Indonesia \\ (Tyashzul@yahoo.com, yantietaslim@yahoo.com,kdmalang@yahoo.com, witarama.akuntan@gmail.com)
}

\begin{abstract}
Due to BNP2TKI ( Indonesian Workers Occupancy and Protection National Board) Crisis Center data of 2013, there are at least 13 thousand cases faced by IMWs working in many countries all over the world. According to Ecosoc (2007), problems faced by IMWs in the destination countries, 80 percent of those come from villages; also Wulan (2011), that Village leaders who do not have adequate knowledge on a safe migration frequently have no power to face PPTKIS (Indonesian Migrant Worker Recruitment and Placement Agencies ). A village actually has strategic roles to prevent trafficking and becomes a foundation of safe migrations since villages are the first exit doors for potential IMWs. The result showed that the head of village would have power through comprehending knowledge about safe migration procedure and requirement; Characteristics of law, culture and payment in placement country; as well as formulating Local Regulation (Perdes)
\end{abstract}

Keywords-Key Words: Village, Safe Migration, Trafficking, Village Regulation.

\section{INTRODUCTION}

Working abroad has been a promising option for most Indonesian people. Nowadays, approximately six million of IMW has been recorded making a living abroad and has sent economic remittance as much as 71 trillion in 2010 (Kompas, 29 November 2011). Meanwhile, according to BNP2TKI, 3, 998,592 IMW consisting of 950,325 male and 3,048,267 female have been migrated to some countries. Most of them $(71.12 \%)$ still work in informal sector as housemaid. Viewed from the placement country, those who work in Saudi Arabia are approximately $1,427,928(35.72 \%)$, then Malaysia as many as 1,049,325 (26.24\%); Taiwan 381,588 (9.2\%); Singapore 228,875 (5.7\%), Arab Emirate Union 220,820 (5.5 $\%)$; Hongkong 214.476 (5.3\%), followed by several countries including Qatar, Jordan, Brunei, Korea, etc (BNP2TKI, 2012). The fact shows that the proportion of women migrants placement has reached $76.2 \%$ of all manpower placements abroad (Wulan, 2015)
Banyumas also one of the potential areas for migrant worker in Indonesia. The number of IMWs from Banyumas Central Java Indonesia always increases significantly. Some sub districts in Banyumas considered as the "pouch" of migrant workers are Lumbir, Kedung Banteng, Gumelar, Cilongok, Karanglewas, Sokaraja, and Baturraden. As one of the potential areas for migrant workers, Banyumas is vulnerable encountering problems and human trafficking. From 2009 to September, 6 cases have been filed. Those occur in sub district of Ajibarang, Gumelar, Rawalo, and Cilongok. Tragically, it is only one case that has been legally taken care (/Trafficking/ official site of Ministry of Coordinator on People Welfare). In 2010, Human trafficking, document forgery, communication breakdown, and depression had been experienced by Banyumas migrant workers as well.

The high number of problems encountered by Banyumas BMI indicates that a strategic mechanism is urgently needed to provide information to Migrants along with their family about a secure migration as the prevention of human trafficking. This is the point in which the empowerment of village chief as the main document provider before going abroad is necessarily carried out. Furthermore, some studies such as Ecosoc (2007) and Wulan (2010) showed that 80 percent of the cases appeared since in the home country through document forgery. Wulan (2011) also revealed that most village chiefs do not have adequate knowledge on secure migration which results in their inability to serve protection for people. In accordance with this background, the research problems are then formulated as follows:

1. What kinds of information and knowledge are needed by village chief in protecting people who are about to or in abroad?

2. What kinds of empowerment models are needed by village chief in protecting people who are about to or in abroad? 


\section{METHOD}

The method used in this study is a qualitative method using in-depth interviewing techniques. Informants are Head of Village at Banyumas Regency. While the supporting informants come from migrant workers, candidate of migrant workers, family/relatives of migrant workers, researcher network on migrant workers, Migrant NGO, A secondary data analysis of the employment policies of both countries is also done to enrich the analysis. This research was taken place in Banyumas Regency.

\section{DISCUSSION}

\section{A. Problems encountered by village chief in protecting people who are about to or in abroad}

Results of FGD and interview identify several problems encountered by village chief in protecting people who are about to or in abroad. The problems cover the powerless village chiefs to deal with broker/sponsor who reach areas in villages yet they would not be responsible for any problem faced by IMWs and the village official who has no autonomy dealing with administration. Besides, in most villages, it is found that workers finally go abroad from another village without being known by their village chief.

Another problem deals with family conflict while IMWs make living abroad or after their return to their hometown. The family conflicts include divorce, being cheated by spouse/squandering money as well as some pregnant female workers by sexual abuse. Through FGD, it discloses that Village officials have no power to control broker/sponsor. Some sponsors violate rule in the way that many IMWs candidates declined by the local officials but they can go abroad through "mutation" to another village without any letter of information from local authorities. Moreover, sponsor sometimes urges local authorities by bringing a letter which "must" be signed by village chief since the candidate of migrant worker has been in Jakarta. The powerless local authorities is also reflected when they assume that District administration (in this case Dinsosnakertrans) trusts the sponsor rather than village administration. The condition gets worse when there is no penalty for those who break the rule. The sponsors themselves have many strategies to attract IMWs candidates as well as their family even the village chief so that they can go abroad. Based on the FGD and interview, conclusion is finally drawn that village chiefs have neither power nor authority to prevent their people from going abroad for working in spite of their incomplete documents. One matter that causes this condition is the poor information as well as knowledge owned by village chiefs concerning with secure migration procedure and requirement.

\section{B. Kinds of information and knowledge which are needed by village chief in protecting people who are about to or in abroad}

After carrying out FGD and some interview with village chief, kinds of information and knowledge which are needed by village chief in protecting people who are about to or in abroad are then identified. Those are explained as follows:

1. Procedure and requirement on a secure migration is suitable to UU No 39 Year 2004 on the IMW Placement and Protection. According to some village chiefs as the informant of the research, the procedure and requirement on secure migration are absolutely needed since the comprehension of this UU make them as 'an authorized and respected party' is able to provide information to the people dealing with right and duty for BMI candidates. The information covers requirement of age, education, salary, etc. The knowledge of UU No. 39 Year 2004 is expected to give protection for BMI candidates before leaving the country, during their working and returning to their hometown.

2. Characteristics of Law, Culture and Payment System in placement country.

Information on characteristics of law, culture, and payment system is needed by village chiefs to provide a description to people dealing with self-protection in placement country. This is also important to avoid some IMWs cases such as those who return home after experiencing sexual abuse, rape event pregnant by their master. Village chiefs also admit that BMIs who want to make a living abroad are inadequately educated. Consequently, most of them do not know at all about culture and law in the placement country. In other words, this condition frequently triggers problem.

\section{Information of legal PPTKIS}

Village chiefs as the local authorities really need information on legal PJTKI/PPTKIS after being recommended by Dinsosnakertrans to protect their people of being illegal IMWs or even human trafficking. Based on their information, Dinsosnakertrans often gave some information dealing with legal PJTKI/PPTKIS or troubled ones yet nowadays such information does not reach their village. Meanwhile, some brokers/sponsors, even from outer Banyumas (Cilacap, Banjarnegara, etc.) persistently persuade IMWs candidates as well as their family without being known whether they are legal or not. Then in case there are any problems with the workers, they would not give any responsibility for it. Instead, that is the village chief that has to solve the problem. From those facts, local authorities expect that brokers/sponsor complete themselves with letter of information issued by Dinsosnakertrans informing that they are legal.

\section{Information in which IMWs stay}

Once IMWs depart from their own country legally, village chiefs require information in which they stay from local administration for any possible unexpected problem. At least, the information may be obtained from text message which consists of address, name of employer, etc. This becomes important since, if the IMWs family got lost contact with them, it indicates they have trouble in their placement country or even died. Unfortunately, it finds it difficult to trace their place due to inaccurate information.

5. Strategies on overcoming some in-trouble IMWs who is either about to or in abroad. 
From FGD, it also reveals that one of the information needed by village chiefs is strategy to give solution for BMIs who have trouble either before or after departure even after the return to their hometown. The lack of information possessed by village chiefs to cope with problems such as steps of handling cases and related parties to contact frequently make the problem, e.g. lost contact, ill, fraud, cannot be resolved immediately. Usually, they rely on their sponsor/PPTKIS. Instead of solving the problem, the sponsor escapes and disappears or even being closed down.

To sum up, those information are urgently needed by village chiefs to empower themselves in facing brokers/sponsors in the effort of protecting BMI who make living abroad.

\section{Kinds of Kinds of empowerment models needed by village chief in protecting people who are about to or in abroad}

After identifying problems encountered by Village chiefs along with kinds of information they need to protect their people, some strategic steps to empower them are then required. Hence, the next step of this research is the researchers initiate to establish cooperation with Agency of Social, Manpower and Transmigration (Dinsosnakertrans), Banyumas Regency and 'Seruni' BMI Association to empower village chiefs in the effort of a secure migration. It is done by holding a training entitled "Village as a Secure Migration Basis". This training was carried out by applying method of lecture, discussion and role play. The purposes of the training are as follows:

1. To improve village chiefs' knowledge on Procedures and Mechanism for a legal and safe migration

2. To improve village chiefs' knowledge on rights and duties of IMWs

3. To improve village chiefs' knowledge on the characteristics of IMWs placement countries

4. To improve village chiefs' knowledge on the treatment of IMWs related cases

Results of this program are Village Chiefs are improved in terms of: comprehending Procedures and Mechanism for a legal and secure BMI; comprehending rights and duties of BMI; comprehending the characteristics of BMI placement countries; being able to provide treatment of BMI-related cases.

Empowering Village chiefs on the information as well as knowledge makes them possess adequate "equipment" as well as enable them to protect their people in terms of engaging negotiation with sponsor, treating cases and thorough explanation on secure migration procedures along with the complexities of culture and law in placement countries. Moreover, local authorities also require formal legality in terms of Local Regulation (Perdes) one of which contains the Authority of Village chiefs concerning with their rights and duties to protect people for secure migration. Some of them have already had Perdes, yet, mostly govern administration affairs dealing with documents needed to go abroad but those which deal with penalty, secure regulation and procedures to go abroad including chief's authority to prohibit illegal BMIs who put them in danger have not yet issued.

\section{CONCLUSION AND RECOMMENDATION}

\section{A. Conclusion}

Migrant workers are not passive object in politics where Research showed that problems encountered by village chiefs to protect his/her people who are about to or in abroad such as the broker who persist on recruiting the people yet irresponsible in case conflicts occurs. Besides, the village has no autonomy dealing with administration ,consequently, it is frequently found in most areas that BMI is finally processed his departure from another village without being known by their head of village. Regarding to this, information and knowledge needed by the village chief include secure migration procedure and requirement in accordance with UU No. 39 Year 2004 on the Placement and Protection for Migrant Workers; Characteristics of law, culture and payment in placement country; information of legal PJTKI/PPTKIS along with the information in which BMI stay. The result showed that the head of village would have power through comprehending those knowledge as well as formulating Local Regulation (Perdes) one of which contains the authority of village chief concerning with right and duty to protect the people in conducting secure migration and prevention from human trafficking.

\section{B. Recommendation}

Village Chiefs would be empowered and possess adequate knowledge if they are equipped by information and comprehension as well about rights and duties of BMI; characteristics of BMI placement countries and treatment of BMI-related cases; Perdes regulating Village chiefs authorities concerning with rights and duties to protect their people in conducting a secure migration and avoid them from human trafficking. It is then expected that by those insights, village chiefs play strategic roles to protect people from human trafficking in the effort of secure migration.

The dissemination of empowerment model for village chiefs and Best Practices By Seruni association in handling cases along with the presence of Maria Bo Niok as an ex BMI who is able to empower her surroundings highly inspired the village chiefs. It leads them to build similar association to empower BMI in their areas. This condition, some village chiefs said, would be an effective way to "secure" their village from illegal migration. Nowadays, two new BMI associations have been established namely Gandatapa and Kawung Carang, Sumbang Sub district. The presence of these associations is highly expected to participate in guiding a process of secure migration in Banyumas.

\section{References}

[1] Ecosoc Rights, 2007 Menangani Perbudakan Modern dari Desa: Rancang Bangun Perbudakan Modern dari Desa, Jakarta 
[2] Wulan, Tyas Retno , 2010 Urgensi Sinergi Antar Lembaga sebagai Strategi Meminimalisir Persoalan TKI, paper presented in Conference on the Institutional Empowerment for Technical Staff Attache in the Effort of Protecting IMWs held by Kemenakertrans, Jakarta 6 December 2010 .

[3] ------,2011 Dalhar Shodiq, Soetji Lestari dan Rili Windiasih 2010 Buruh Migran Perempuan Melawan Negara dan Pasar dengan Remitansi Sosial, Journal of Analisis Sosial Vol 15 No. 2 December 2010

[4] -------, Dalhar Shodiq, Sri Wijayanti, Margani Pinasti 2013 Strengthening Social and Economic Remmitance as a Strategy to the empower of Indonesian Migrant Workers (IMW), Poverty Alleviation Confrence Jakarta 12-13 Juni 2013

[5] ------, 2015 From From Zero to Hero: How Migrants Workers Change the World, presented International Conference on "Gendered Dimensions of Migration: Material and social outcomes of SouthSouth Migration", National University of Singapore

[6] Trafficking/ official site of Ministry of Coordinator on People Welfare)

[7] Kompas, 29 November 2011 